\title{
Model Panjang Antrian Kendaraan pada Perlintasan Sebidang Tanpa Palang Pintu (Studi Kasus: Perlintasan Sebidang Jl. Gayung Kebonsari Surabaya)
}

\author{
Adita Utami ${ }^{1}$, Hera Widyastuti ${ }^{1, *}$ \\ Departemen Teknik Sipil, Institut Teknologi Sepuluh Nopember, Surabaya \\ Koresponden*, Email: hera.widyastuti@yahoo.co.uk
}

\begin{tabular}{lr}
\hline & Info Artike \\
\hline Diajukan & 15 Januari 2018 \\
Diperbaiki & 31 Januari 2019
\end{tabular}

Disetujui 09 Februari 2019

Keywords: railway level crossings, vehicle queue, early warning, mutiple linear regression
Kata kunci: perlintasan sebidang, panjang antrian, early warning, analisa regresi berganda \begin{abstract}
Population growth and the development of economy in Indonesia affect the increase in vehicle volume, especially in the city of Surabaya. The increasing of vehicles volume, causing congestion at some points in Surabaya including Gayung Kebonsari. One of the congestion factors at the railway level crossings is the duration of closing time as the train passes through the crossing. Considering of those problems, two models developed, those are: the queuing of traffic length and with considering of length and speed of the train, and queue length. Data have been collected and analyzed by making the model relationship with simple linear regression method. Based on the research, the result shown that there are positive relationship of the train length, train speed, and the length of closing time, $y=1.7204 x_{1}-0.073 x_{2}+56.39$. Where $y$ is the length of closing time, $x_{1}$ is the train length and $x_{2}$ is train velocity. However, the train speed has negative relationship. The equation means every additional length of train means additional closing time equals to 1.7204 seconds, and $\mathbf{- 0 . 0 7 3}$ means the velocity of train has negative effect for the length of railway level crossing closing time. It means additional velocity equals to $1 \mathrm{~km} / \mathrm{h}$ will decrease $0.073 \mathrm{~s}$ of railway level crossing closing time.
\end{abstract}

\begin{abstract}
Abstrak
Pertumbuhan penduduk dan perkembangan ekonomi di Indonesia mempengaruhi peningkatan volume kendaraan, terutama di kota Surabaya. Peningkatan volume kendaraan, menyebabkan kemacetan di beberapa titik di Surabaya. Salah satu faktor kemacetan di perlintasan kereta api adalah durasi waktu penutupan saat kereta melewati persimpangan. Durasi penutupan perlintasan yang tidak pasti menyebabkan pengguna jalan menjadi tidak disiplin dengan menerobos perlintasan yang berakibat pada meningkatnya tingkat kecelakaan lalu lintas yang terjadi di persimpangan sebidang tidak berpalang pintu. Sehingga perlu dibuat dua model hubungan antar variabel. Model pertama yaitu hubungan antara lama waktu penutupan perlintasan dengan jumlah rangkaian dan kecepatan kereta, dan model kedua yaitu hubungan antara lama waktu penutupan perlintasan dengan panjang antrian kendaraan. Digunakan metode regresi berganda untuk membuat model tersebut. Hasil model regresi hubungan antara lama waktu penutupan perlintasan sebidang dengan panjang dan kecepatan kereta memiliki pengaruh positif dengan model hubungannya yaitu: $\mathrm{y}=1.7204 \times 1-0.073 \times 2+56.39$. Dengan y adalah lama waktu penutupan, x1 adalah panjang kereta, dan x2 adalah kecepatan kereta. Setiap pertambahan satu rangkaian kereta bertambah pula lama waktu penutupan sebesar 1.7204 detik, serta arti dari 0.073 berarti bertambahnya kecepatan $1 \mathrm{~km} / \mathrm{jam}$ maka akan menurunkan 0.073 detik lama waktu penutupan perlintasan sebidang.
\end{abstract}

\section{Pendahuluan}

Pertumbuhan penduduk serta peningkatan ekonomi di Indonesia berdampak meningkatnya volume kendaraan di Kota-kota besar di Indonesia termasuk kota Surabaya. Menurut Badan Pusat Statistik Kota Surabaya 2017, rata-rata partumbuhan penduduk Surabaya yaitu 2.136 \% tiap tahunnya [1]. Serta pertumbuhan volume kendaraan bermotor di Kota Surabaya terus meningkat sekitar 5-6 \% tiap tahunnnya [2]. Dengan bertambahnya volume kendaraan menyebabkan kemacetan di beberapa titik di Surabaya. Salah satu titik kemacetan di Surabaya adalah kemacetan yang disebabkan adanya perlintasan sebidang tanpa palang pintu di daerah Gayung
Kebonsari. Berdasarkan peraturan yang ada, saat perjalanan kereta api melewati perlintasan sebidang harus dilakukan penutupan pintu perlintasan dan terjadi penghentian sementara terhadap arus lalu lintas jalan raya sehingga menimbulkan salah satu dampak yaitu terjadinya tundaan (delay) lalu lintas bagi pengguna jalan raya [3]. Hal ini sesuai dengan UndangUndang no. 23 tahun 2007 pasal 124 yang menyatakan bahwa: "pada perpotongan sebidang antara jalur kereta api dan jalan, pemakai jalan wajib mendahulukan perjalanan kereta api”, sehingga apabila perlintasan kedua moda masih sebidang harus dilakukan penutupan lintasan jalan pada saat kereta api melintas di suatu persimpangan [4]. 
Bertambahnya volume kendaraan bermotor dan partumbuhan pemukiman penduduk yang semakin pesat berpengaruh terhadap meningkatnya intensitas perjalanan yang berakibat pada meningkatnya dorongan akses langsung ke pusat Kota [5]. Di sisi lain, pertumbuhan pemukiman penduduk yang semakin pesat juga menimbulkan adanya permintaan akses melalui moda transportasi dengan kapasitas besar yang melalui jalur kereta api. Hal tersebut menimbulkan kemacetan terutama di sekitar perlintasan sebidang seperti di Gayung Kebonsari. Kemacetan akibat adanya penutupan perlintasan sebidang di daerah Gayung Kebonsari terus meningkat seiring dengan pertumbuhan pemukiman penduduk yang semakin pesat. Salah satu faktor kemacetan pada perlintasan sebidang yaitu lama waktu penutupan sebelum kereta melewati perlintasan dan saat kereta melewati perlintasan tersebut [3]. Lama penutupan perlintasan memberikan pengaruh yang signifikan terhadap besarnya tundaan dan panjang antrian [6]. Lama waktu saat kereta melewati perlintasan tersebut tergantung oleh panjang kereta dan faktor lainnya. Dari permasalahan tersebut perlu dibuat suatu model hubungan antara penutupan perlintasan sebidang, panjang dan kecepatan kereta serta panjang antrian kendaraan di daerah Gayung Kebonsari Surabaya. Jalan Gayung Kebonsari perlu ditinjau karena jalan merupakan jalan yang cukup padat lalu lintasnya. Pada Jalan Gayung Kebonsari ini terdapat beberapa tempat penting yang sering menimbulkan tarikan perjalanan melalui jalan ini. Beberapa lokasi penting yang berada di daerah ini yaitu Rumah Sakit Mata Masyarakat Jawa Timur, Sekolah Islam Al-Hikmah Surabaya, beberapa tempat makan terkenal di Surabaya, dan berdekatan dengan kampus Universitas Negeri Surabaya.

\section{Metode}

\section{Pengumpulan Data}

Tahap awal pada penelitian ini adalah mengumpulkan data primer yang dibutuhkan, yaitu membuat jadwal kereta yang melalui perlintasan sebidang di Jalan Gayung Kebonsari, data geometrik (lebar perkerasan, lebar bahu jalan, lebar trotoar, jumlah lajur dan lebar lajur), data volume kendaraan, lama waktu penutupan, panjang antrian kendaraan, panjang kereta dan kecepatan kereta. Adapun volume kendaraan yang dihitung yaitu Kendaraan Ringan (KR), Kendaraan Berat $(\mathrm{KB})$, sepeda motor (SM), dan Kedaraan tidak bermotor (KTB).

\section{Analisis Data}

Pada Tahap analisis akan dilakukan analisis pada data lalu lintas ketika tidak ada kereta lewat dan saat kereta lewat, kemudian akan didapatkan kapasitas (C) dan derajat kejenuhan (DS) saat sebelum dan sesudah kereta lewat, lama waktu penutupan dan perhitungan panjang antrian kendaraan dengan metode shockwave [8].

Pada saat penutupan perlintasan sebidang, maka akan terjadi penundaan kendaraan yang menyebabkan antrian [9]. Maka pada pelaksanaan analisis lalu lintas, dihitung panjang dan perilaku antrian pada saat perlintasan mulai ditutup hingga perlintasan kembali terbuka dan arus lalu lintas kembali normal. Analisis yang digunakan dalam menganalisa antrian menggunakan metode shocked wave. Selain itu, pada analisis lalu lintas juga dihitung kapasitas simpang pada persimpangan dengan acuan dari Panduan Kapasitas Jalan Indonesia (PKJI) tahun 2014.

\section{Pembuatan Model}

Hasil analisis data yang berupa karakteristik lalu lintas kemudian diolah untuk menghasilkan suatu model hubungan antara panjang kereta, waktu penutupan perlintasan sebidang, dan panjang antrian kendaraan. Metode statistika yang digunakan untuk membuat model hubungan antara panjang dan kecepatan kereta dengan lama waktu penutupan perlintasan sebidang, adalah analisis regresi linier berganda. Sedangkan untuk membuat model hubungan antara lama waktu penutupan perlintasan dan panjang antrian, digunakan analisis regresi linier sederhana. Analisis regresi linier berganda digunakan untuk mendapatkan hubungan lebih dari satu variabel, sedangkan regresi linier sederhana digunakan untuk mendapatkan hubungan matematis dalam bentuk suatu persamaan antara variabel tak bebas tunggal dengan variabel bebas tunggal [10]. Regresi linier sederhana hanya memiliki satu peubah yang dihubungkan dengan satu peubah tidak bebas, dengan bentuk $y=a x+b$ [7]. Untuk program bantu yang digunakan adalah SPSS dan Microsoft excel.

\section{Kesimpulan dan Saran}

Pengambilan kesimpulan berdasarkan hasil yang didapatkan pada tahap analisis. Penelitian ini diharapkan dapat menjadi bahan pertimbangan dalam merancang pembangunan early warning pada perlintasan sebidang kereta api dan jalan raya. Selanjutnya, penelitian ini diharapkan menjadi bahan referensi dalam melakukan kajian maupun penelitian lebih lanjut terkait early warning.

\section{Hasil dan Pembahasan}

\section{Satuan Kendaraan Ringan (SKR)}

Data volume kendaraan yang telah didapatkan kemudian dikalikan nilai Ekivalen Kendaraan Ringan (EKR) untuk perkotaan dengan tipe jalan 2/2 TT. Nilai EKR untuk Kendaraan Ringan yaitu 1, Kendaraan Berat yaitu 1.3 dan Sepeda Motor yaitu 0.4 [11]. Sehingga didapatkan nilai Satuan Kendaraan 
Ringan (SKR). Setelah menentukan Satuan Kendaraan Ringan, dilakukan pencarian SKR pada jam puncak (peak hour) di Jalan Gayung Kebonsari. Perhitungan dengan cara menjumlahkan SKR semua pendekat masing masing jalan per 15 menit, kemudian di akumulasi per jam untuk mendapatkan jam puncak. Dari perhitungan diatas maka dapat disimpulkan bahwa peak hour kendaraan di Jalan Gayung Kebonsari yaitu pada pukul 07.00-08.00 dengan volume 1724 skr/jam.

\section{Kapasitas Jalan}

Perhitungan kapasitas jalan (C) bertujuan untuk mengetahui kemampuan suatu ruas dalam menampung jumlah kendaraan per satuan jam (SKR/jam) pada jalan eksisting [12]. Berdasarkan Pedoman Kapasitas Jalan Indonesia, untuk menghitung Kapasitas Jalan dapat menggunakan rumus [11]:

$\mathrm{C}=\mathrm{C}_{0} \times \mathrm{FC}_{\mathrm{LJ}} \times \mathrm{FC}_{\mathrm{PA}} \times \mathrm{FC}_{\mathrm{HS}} \times \mathrm{FC}_{\mathrm{UK}}$

\section{Keterangan:}

C : kapasitas jalan, skr/jam

C0 : kapasitas dasar, skr/jam

FCLJ : faktor kapasitas terkait lebar lajur

FCPA : faktor kapasitas terkait pemisahan arah

FCHS : faktor kapasitas terkait Hambatan samping

FCUK : faktor kapasitas terkait ukuran Kota

Dengan melihat Kapasitas dasar dan berbagai faktor penyesuaian kapasitas jalan, maka didapatkan kapasitas Jalan Gayung Kebonsari yaitu 2473 SKR/jam. Tipe jalan Gayung Kebonsari ini yaitu 2/2 TT.

\section{Derajat Kejenuhan}

Jalan yang ditinjau dievaluasi dengan melihat nilai derajat kejenuhan (Dj) yang didapat dari perbandingan volume dengan kapasitas jalan. Dimana bila nilai Dj mendekati 0 maka segmen jalan tersebut kondisi lengang dan mendekati 1 maka jalan tersebut mendekati kapasitas jalan yang seharusnya atau mengalami kejenuhan [11].

Menurut Pedoman Kapasitas Jalan Indonesia, nilai derajat kejenuhan dapat dihitung menggunakan rumus [11]:

$$
\mathrm{Dj}=\mathrm{Q} / \mathrm{C}
$$

Dengan:

Dj : Nilai derajat kejenuhan

Q : Volume lalu lintas (Skr/Jam)

C : Kapasitas jalan eksisting (Skr/Jam)

Maka didapat nilai derajat kejenuhan pada jalan Gayung Kebonsari yaitu 0.74 .

\section{SKR saat Kereta Melewati Perlintasan Sebidang}

Pada perhitungan analisa lalu lintas PKJI dibutuhkan data volume kendaraan per jam, namun pada analisa kendaraan saat kereta api melewati perlintasan data yang diperoleh yaitu volume kendaraan yang terhenti akibat kereta api lewat dimana waktu siklusnya yaitu lama waktu penutupan perlintasan dalam satuan detik. Oleh sebab itu diperlukan konversi data volume kendaraan ringan dari satu siklus menjadi satuan kendaraan ringan per jam.

Adapun contoh hasil perhitungan konversi satuan kendaraan ringan pada pukul 06.23 di jalan Gayung Kebonsari terdapat pada Tabel 1.

Tabel 1 Hasil Konversi SKR pada Jalan

\begin{tabular}{ccccc}
\hline Jalan & Pendekat & $\begin{array}{c}\text { V. terhenti } \\
\text { skr/skls }\end{array}$ & Siklus & $\begin{array}{c}\text { Konversi } \\
\text { Skr/jam }\end{array}$ \\
\hline Jl. Gayung & $\mathrm{B}$ & 9 & 70 & 483 \\
Kebonsari & $\mathrm{T}$ & 6 & 72 & 300 \\
\hline
\end{tabular}

Derajat Kejenuhan saat Kereta Melewati Perlintasan Sebidang

Perhitungan kapasitas dan derajat kejenuhan saat kereta melewati perlintasan sama dengan cara sebelumnya. Kondisi geometri dan kondisi lingkungan Jalan Gayung Kebonsari tidak berubah sehingga kapasitas jalan untuk tersebut adalah $2473 \mathrm{SKR} / \mathrm{jam}$. Sehingga DJ $=(483+300) / 2473=0.32$.

\section{Analisa panjang antrian}

Kemudian dilakukan analisis panjang antrian. Pada tahap ini akan menghitung panjang antrian menggunakan queueing analysis yang merupakan rumusan turunan dari rumus shocked wave. Pada perhitungan antrian menggunakan queueing analysis akan didapat TQ (durasi waktu antrian), QM (Antrian kendaraan), dan panjang antrian. Adapun rumus yang akan digunakan yaitu [13]:

$$
\begin{aligned}
& T Q=\frac{\mu \cdot r}{\mu-\lambda} \\
& Q M=\frac{\lambda r}{3600}
\end{aligned}
$$

\section{Contoh perhitungan panjang antrian:}

Pada Jalan Gayung Kebonsari 24 Mei 2018, pukul 08:04 yaitu:

$\mu \quad=2473 \mathrm{SKR} / \mathrm{jam}$

$\mathrm{r} \quad=70$ detik

$\lambda=607 \mathrm{SKR} / \mathrm{jam}$

Sehingga diperoleh durasi antrian :

$\mathrm{TQ}=(2473 \times 70) /(2473-607)=92,76$ detik 
Panjang antrian kendaraan dalam satuan kendaraan ringan:

$\mathrm{QM}=\lambda \mathrm{r} /(3600)$

$=(70 x 607) /(3600)=12 \mathrm{SKR}$.

Dimana satuan kendaraan ringan diasumsikan sebagai kendaraan pribadi dengan panjang kendaraan yaitu 3 meter sehingga panjang antrian:

$\mathrm{QM}=12 \times 3=36$ meter

Analisis Perbandingan Antara Panjang Antrian Real Lapangan dan Perhitungan Queueing analysis

Analisis Perbandingan Antara Panjang Antrian Real Lapangan dan Perhitungan queueing analysis. Pada tahap ini dalam mengukur panjang antrian kendaraan menggunakan 2 metode yaitu manual atau survey lapangan dengan menggunakan meteran dan dicatat oleh surveyor dan yang kedua menggunakan rumusan queueing analysis. Kemudian dibandingan hasil panjang antrian survey lapangan dengan perhitungan queueing analysis dengan menggunakan metode ANOVA. Hasil uji ANOVA antrian kendaraan pada perlintasan Jl. Gayung Kebonsari pendekat Barat dapat dilihat pada Tabel 2, sedangkan hasil uji ANOVA antrian kendaraan pada perlintasan Jl. Gayung Kebonsari pendekat Timur dapat dilihat pada Tabel 3.

\section{Uji Hipotesis}

Ho : Rata-rata hasil panjang antrian survey lapangan dengan perhitungan rumus semua sama.

H1 : Rata-rata hasil panjang antrian survey lapangan dengan perhitungan rumus tidak sama.

$H_{0}: A_{1}=A_{2}$

$H_{1}: A_{1} \neq A_{2}$

Membandingkan dengan taraf signifikan, alfa $(\alpha)=0,05$ $\left.\begin{array}{c}\text { jika } F_{\text {hitung }} \geq F_{\text {tabel }} \\ \text { P-value }<\alpha\end{array}\right\} \quad$ maka tolak $H_{0}$, terima $\mathrm{H}_{1}$

Dari hasil ANOVA diatas didapatkan hasil F hitung dan juga P-value. Kedua parameter tersebut akan digunakan untuk menentukan hipotesis mana yang akan diterima dan akan ditolak. Rekap F hitung dan P value dari semua proses dapat dilihat pada Tabel 4.

\section{Persamaan Model}

Dalam penelitian ini akan dibuat model hubungan menggunakan metode regresi linier berganda. Model hubungan yang dibuat yaitu antara waktu penutupan perlintasan sebidang dengan panjang rangkaian kereta dan kecepatan kereta, serta model hubungan waktu lama antrian kendaraan dengan panjang antrian rumus dan panjang antrian survey lapangan. Dari hasil analisis menggunakan program bantu SPSS, didapatkan hasil pada Tabel 5.

Tabel 2 Analysis of Variance Jalan Gayung Kebonsari Pendekat Barat

\begin{tabular}{lrrrrrr}
\hline $\begin{array}{l}\text { Source of } \\
\text { Variation }\end{array}$ & \multicolumn{1}{c}{ SS } & df & MS & $F$ & P-value & $\begin{array}{c}F \\
\text { crit }\end{array}$ \\
\hline Between & & & & & & \\
Groups & 26.45 & 1 & 26.46 & 0.19 & 0.658 & 3.95 \\
Within & & & & & & \\
Groups & 11306.05 & 84 & 134.59 & & & \\
Total & 11332.51 & 85 & & & & \\
\hline
\end{tabular}

Tabel 3 Analysis of Variance Jalan Gayung Kebonsari Pendekat Timur

\begin{tabular}{lrrrrrr}
\hline $\begin{array}{l}\text { Source of } \\
\text { Variation }\end{array}$ & \multicolumn{1}{c}{ SS } & $d f$ & $M S$ & $F$ & $\begin{array}{c}P- \\
\text { value }\end{array}$ & $\begin{array}{c}F \\
\text { crit }\end{array}$ \\
\hline $\begin{array}{l}\text { Between } \\
\text { Groups }\end{array}$ & 5.079 & 1 & 5.07 & 0.01 & 0.92 & 3.95 \\
Within & & & & & & \\
Groups & 40526.86 & 84 & 482.46 & & & \\
Total & 40531.94 & 85 & & & & \\
\hline
\end{tabular}

Dari analisis data pada Tabel 5 diperoleh persamaan model pada jalan Gayung Kebonsari:

$Y=1.7204 x_{1}-0.073 x_{2}+56.39$

Dengan:

$\mathrm{Y}=$ Lama waktu penutupan perlintasan sebidang

$\mathrm{x}_{1}=$ Jumlah rangkaian kereta

$\mathrm{x}_{2}=$ Kecepatan kereta

Arti dari persamaan tersebut yaitu setiap pertambahan satu rangkaian kereta bertambah pula lama waktu penutupan sebesar 1.7204 detik, serta arti dari -0.073 berarti bertambahnya kecepatan $1 \mathrm{~km} / \mathrm{jam}$ maka akan menurunkan 0.073 detik lama waktu penutupan perlintasan sebidang.

Dari hasil analisis data pada Tabel 5 juga didapat uji signifikan data dengan hasil P-value panjang rangkaian yaitu 1.15E-18 lebih kecil dari alfa dimana alfa yang digunakan yaitu 0.05 maka dapat dinyatakan bahwa jumlah rangkaian kereta terdapat hubungan yang signifikan terhadap lama waktu perlintasan sebidang. Sedangkan kecepatan rangkaian kereta dengan P-valuenya 0.0116035 kurang dari alfa maka kecepatan kereta terdapat hubungan signifikan terhadap lama waktu penutupan perlintasan sebidang. Tabel 6 menunjukkan nilai R-Square dari hasil regresi model hubungan antara 
waktu penutupan perlintasan sebidang dengan panjang rangkaian kereta dan kecepatan kereta.

Tabel 6 R-Square dari hasil regresi model hubungan antara waktu penutupan perlintasan sebidang dengan panjang rangkaian kereta dan kecepatan kereta

\begin{tabular}{lr}
\hline \multicolumn{2}{c}{ Regression Statistics } \\
\hline Multiple R & 0.963501 \\
R Square & 0.928334 \\
Adjusted R Square & 0.924658 \\
Standard Error & 1.433834 \\
Observations & 42 \\
\hline
\end{tabular}

Dari output nilai R square yang didapatkan sebesar 0,928. Nilai ini mengandung arti bahwa pengaruh panjang rangkaian kereta dan kecepatan terhadap lama waktu sebesar 92,8\% sedangkan 8,2\% lama waktu dipengaruhi oleh variabel lain yg tidak diteliti.

Selajutnya yaitu model hubungan antara lama waktu penutupan dengan panjang antrian kendaraan menggunakan data survey lapangan antara lama waktu penutupan dan panjang antrian kendaraan lapangan dan juga data perhitungan rumus queueing analysis panjang antrian. Pada model hubungan ini terbagi menjadi 2 yaitu sesuai dengan arah pendekat yaitu, jalan Gayung Kebonsari dengan arah pendekat Barat dan jalan Gayung Kebonsari dengan arah pendekat Timur. Pada data yang digunakan Y adalah lama waktu penutupan dan Y adalah panjang antrian. Hasil regresi linier hubungan lama waktu penutupan dengan panjang antrian rumus Jalan Gayung Kebonsari arah Pendekat Barat dapat dilihat pada Gambar 1.

Persamaan model hubungan lama waktu penutupan dengan panjang antrian rumus Jalan Gayung Kebonsari arah Pendekat Barat yang terbentuk adalah $\mathrm{y}=0.5064 \mathrm{x}-4.9584$ dengan nilai R-Square adalah 0.6107. Persamaan tersebut menggandung arti 1 detik waktu perlintasan bertambah maka akan menambah panjang antrian sebesar 0.5064 meter. Untuk persamaan model yang terbentuk dari hasil analisis hubungan Lama waktu penutupan dengan panjang antrian rumus Jalan Gayung Kebonsari arah Pendekat Barat adalah y $=0.4724 \mathrm{x}$ 35705 dengan nilai R-Square adalah 0.583. Persamaan tersebut menggandung arti 1 detik waktu perlintasan bertambah maka akan menambah panjang antrian sebesar 0.4724 meter.

Panjang antrian pada Jalan Gayung Kebonsari arah pendekat timur perlu ditinjau karena Jalan Gayung Kebonsari merupakan jalan yang sukup padat lalu lintasnya. Dengan arus lalu lintas perjam saat peak hour mencapai 1724 SKR/jam. Sehingga pada saat kereta api melewati perlintasan maka akan terjadi antrian yang mengakibatkan tundaan pada kendaraan. Model hubungan lama waktu penutupan dengan panjang antrian rumus dapat dilihat pada Gambar 3, sedangkan model hubungan lama waktu penutupan dengan panjang antrian survey lapangan dapat dilihat pada Gambar 4.

Persamaan model yang terbentuk dari hubungan lama waktu penutupan dengan panjang antrian survey lapangan Jalan Gayung Kebonsari arah Pendekat Timur adalah y = 1.2171x - 39.912 dengan nilai R-Square adalah 0.6499. Persamaan tersebut menggandung arti 1 detik waktu perlintasan bertambah maka akan menambah panjang antrian sebesar 1.217 meter. Sedangkan Persamaan model yang terbentuk adalah $\mathrm{y}=1.1741 \mathrm{x}-38.165$ dengan nilai R-Square adalah 0.6849. Persamaan tersebut menggandung arti 1 detik waktu perlintasan bertambah maka akan menambah panjang antrian sebesar 1.1741 meter.

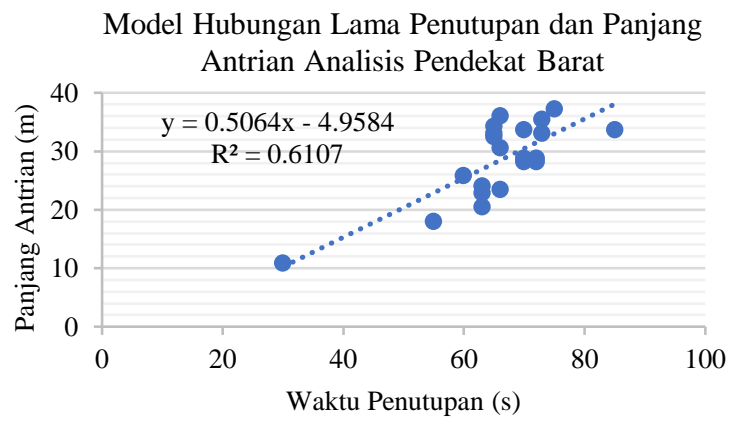

Gambar 1. Grafik regresi linier hubungan lama waktu penutupan dengan panjang antrian rumus Jalan Gayung Kebonsari arah pendekat barat

Model Hubungan Lama Penutupan dan Panjang Antrian Real Lapangan Pendekat Barat

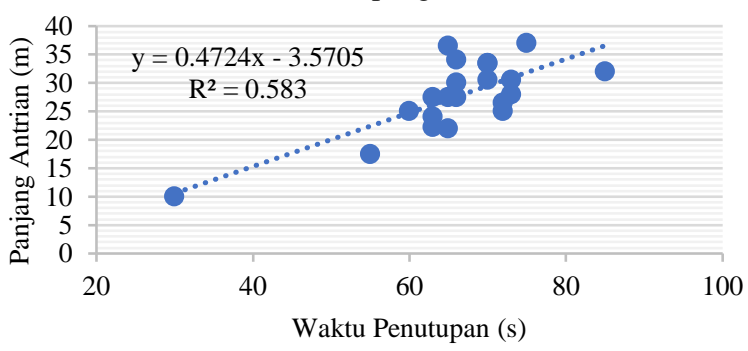

Gambar 2. Grafik regresi linier hubungan lama waktu penutupan dengan panjang antrian rumus Jalan Gayung Kebonsari arah pendekat barat

Dari seluruh hasil persamaan model yang telah terbentuk, dibuat ringkasan hasil persamaan model regresi pada Jalan Gayung Kebonsari. Ringkasan hasil persamaan dapat dilihat pada Tabel 7 sampai Tabel 10. 
Model Hubungan Lama Penutupan dan Panjang Antrian Analisis Pendekat Barat

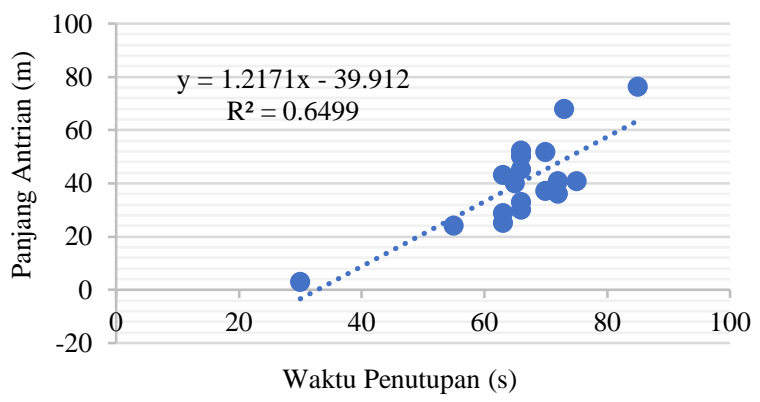

Gambar 4. Grafik regresi linier hubungan lama waktu penutupan dengan panjang antrian survey lapangan Jalan Gayung Kebonsari arah pendekat timur

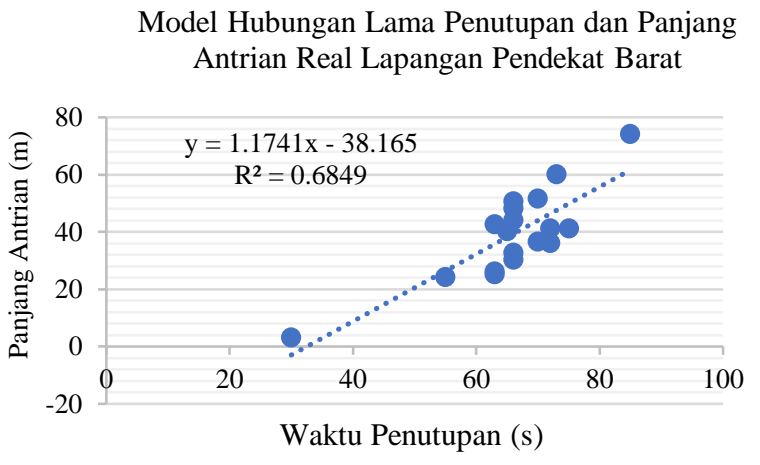

Gambar 5. Grafik regresi linier hubungan lama waktu penutupan dengan panjang antrian real lapangan Jalan Gayung Kebonsari arah pendekat timur

\section{Simpulan}

Beberapa kesimpulan yang didapat dari beberapa hasil yang telah dibuat pada penelitian ini adalah sebagai berikut.

1. Hasil analisis regresi hubungan antara panjang kereta (jumlah kereta/gerbong) lama waktu penutupan perlintasan sebidang memiliki pengaruh yang signifikan
2. Hasil model regresi hubungan antara lama waktu penutupan perlintasan sebidang dengan panjang kereta dan kecepatan kereta pada Jalan Gayung Kebonsari memiliki pengaruh positif dengan model hubungannya yaitu $\mathrm{y}=$ $1.7204 x_{1}-0.073 x_{2}+56.39$. Dengan y adalah lama waktu penutupan perlintasan, $\mathrm{x}_{1}$ adalah panjang kereta dan $\mathrm{x}_{2}$ adalah kecepatan kereta. Setiap pertambahan satu rangkaian kereta bertambah pula lama waktu penutupan sebesar 1.7204 detik, serta arti dari - 0.073 berarti bertambahnya kecepatan $1 \mathrm{~km} / \mathrm{jam}$ maka akan menurunkan 0.073 detik lama waktu penutupan perlintasan sebidang.

3. Hasil analisis regresi antara lama waktu penutupan perlintasan sebidang dengan panjang antrian survey lapangan pada setiap arah pada persimpangan Jalan Gayung Kebonsari memiliki hubungan positif dengan model $\mathrm{y}=0.5064 \mathrm{x}-4.9584$ untuk arah pendekat barat. Persamaan tersebut menggandung arti 1 detik waktu perlintasan bertambah maka akan menambah panjang antrian sebesar 0.5064 meter. Persamaan arah pendekat timur y $=1.2171 \mathrm{x}-39.912$. Persamaan tersebut menggandung arti 1 detik waktu perlintasan bertambah maka akan menambah panjang antrian sebesar 1.217 meter.

4. Hasil analisis regresi antara lama waktu penutupan perlintasan sebidang dengan panjang antrian menggunakan rumusan pada setiap arah pada persimpangan Jalan Gayung Kebonsari memiliki hubungan positif dengan model $\mathrm{y}=0.4724 \mathrm{x}-35705$ untuk arah pendekat barat. Persamaan tersebut menggandung arti 1 detik waktu perlintasan bertambah maka akan menambah panjang antrian sebesar 0.4724 meter. Persamaan arah pendekat timur y $=1.1741 \mathrm{x}-38.165$. Persamaan tersebut menggandung arti 1 detik waktu perlintasan bertambah maka akan menambah panjang antrian sebesar 1.1741 meter.

Tabel 4. Rekap F hitung dan $P$ value

\begin{tabular}{cclccccc}
\hline Jalan & Arah & \multicolumn{9}{c}{ Kesimpulan } & & Keterangan \\
\hline \multirow{2}{*}{ Gayung } & \multirow{2}{*}{ Barat } & Fhitung & 0.197 & $<$ & F Tabel & 3.955 & Ho diterima, \\
Kebonsari & & P-Value & 0.659 & $>$ & $\alpha$ & 0.05 & H1 ditolak \\
& \multirow{2}{*}{ Timur } & Fhitung & 0.011 & $<$ & F Tabel & 3.955 & Ho diterima, \\
& & P-Value & 0.919 & $>$ & $\alpha$ & 0.05 & H1 ditolak \\
\hline
\end{tabular}

Tabel 5. Output persamaan model dan signifikan Jalan Gayung Kebonsari

\begin{tabular}{lrrrr}
\hline & Coefficients & Standard Error & t Stat & \multicolumn{1}{c}{ P-value } \\
\hline Intercept & 56.39626 & 2.705268 & 20.84683 & $9.48 \mathrm{E}-23$ \\
Jumlah Rangkaian & 1.720459 & 0.107999 & 15.93035 & $1.15 \mathrm{E}-18$ \\
Kecepatan (Km/jam) & -0.07327 & 0.045585 & -1.6074 & 0.0116035 \\
\hline
\end{tabular}


Tabel 7 Hubungan lama waktu perlintasan sebidang dengan panjang antrian rumusan Pendekat Barat Jl. Gayung Kebonsari

\begin{tabular}{cllr}
\hline No & Metode Regresi & Persamaan Model & Nilai R-Square \\
\hline 1 & Regresi Linier & $\mathrm{Y}=0.5064 \mathrm{x}-4.9584$ & 0.6107 \\
\hline
\end{tabular}

Tabel 8 Hubungan lama waktu perlintasan sebidang dengan panjang antrian Survey Lapangan Pendekat Barat Jl. Gayung Kebonsari

\begin{tabular}{cllr}
\hline No & Metode Regresi & Persamaan Model & Nilai R-Square \\
\hline 1 & Regresi Linier & $\mathrm{Y}=0.4724 \mathrm{x}-35705$ & 0.583 \\
\hline
\end{tabular}

Tabel 9 Hubungan lama waktu perlintasan sebidang dengan panjang antrian rumusan Pendekat Barat Jl. Gayung Kebonsari

\begin{tabular}{cllr}
\hline No & Metode Regresi & Persamaan Model & Nilai R-Square \\
\hline 1 & Regresi Linier & $\mathrm{Y}=1.2171 \mathrm{x}-39.912$ & 0.6499 \\
\hline
\end{tabular}

Tabel 10 Hubungan lama waktu perlintasan sebidang dengan panjang antrian Survey Lapangan Pendekat Barat Jl. Gayung Kebonsari

\begin{tabular}{cllr}
\hline No & Metode Regresi & Persamaan Model & Nilai R-Square \\
\hline 1 & Regresi Linier & $\mathrm{Y}=1.1741 \mathrm{x}-38.165$ & 0.6849 \\
\hline
\end{tabular}

\section{Daftar Pustaka}

[1] Badan Pusat Statistik Kota Surabaya, "Surabaya dalam Angka 2016,” 2016.

[2] Badan Pusat Statistik Kota Surabaya, "Surabaya dalam Angka 2017,” 2017.

[3] G. Gruyter, C.D. dan Currie, "Rail Road Crossing Impact: An International Synthesis"," Transp. Rev., vol. 36, no. ed Routledge, pp. 793-815, 2016.

[4] “Uu_No_23_Tahun_2007.Pdf.” 2007.

[5] I. Joenaini, "Analisis Dampak Lalu Lintas bagi Perumahan Sebagai Upaya Mengatasi Kepadatan Lalu Lintas Kabupaten,” pp. 269-289, 2014.

[6] A. S. Amal, B. Pudjianto, and E. Mujihartono, "Pengaruh Penutupan Pintu Perlintasan Kereta Api Terhadap Tundaan Dan Panjang Antrian Kendaraan Pada Jalan Raya Malang - Surabaya KM.10," Pilar, vol. 11, no. 2, pp. 88-91, 2002.

[7] O. Z. Tamin, Perencanaan dan Pemodelan Transportasi, Edisi Kedua. 2003.

[8] B. Studi, K. Jl, A. Jl, B. Palar, J. A. Timboeleng, and S. Y. R. Rompis, "Analisa Gelombang Kejut pada Persimpangan,” vol. 4, no. 9, pp. 559-566, 2016.

[9] Irawati, "Pengaruh Derajat Kejenuhan Jalan Terhadap Tundaan Dan Panjang Antrian Pada Pintu Lintasan Kereta Api Dengan Variasi Lama Penutupan Jalan Studi Kasus Pintu Lintasan 1, Jalan Pecindilan Surabaya,” Institut Teknologi Sepuluh Nopember, 2001.

[10] J. Supranto, "Statistik teori dan aplikasi jilid 1 / oleh J. Supranto," Stat. Teor. dan Apl. jilid 1 / oleh J. Supranto, 2000.

[11] D. G. of H. D. of U. R. Directorate General Bina Marga, "Highway Capacity Manual Project ( Hcm )," vol. 1, no. I, p. 564, 1997.
[12] B. S. Koloway, "Kinerja Ruas Jalan Perkotaan Jalan Prof Dr . Satrio, DKI Jakarta,” J. Perenc. Wil. dan Kota, vol. 20, no. 3, p. hlm 215-230, 2009.

[13] Adolf .D May, Traffic Flow Fundamentals. Amerika: Prentice-Hall.Inc, 1990. 
